To Maega $\mid$ Jurnal Pengabdian Masyarakat

Agustus 2021, Vol.4, No.2, hal, 115-123

$\operatorname{ISSN}(P): 2622-6332 ; \operatorname{ISSN}(E): 2622-6340$

http://www.ojs.unanda.ac.id/index.php/tomaega

\title{
Edukasi Penyusunan Laporan Keuangan Badan Usaha Milik Negeri (BUMneg) Ulihalawang Hitumessing
}

\author{
Ishak Ishak ${ }^{1}$, Fajrul Rahman Slamat1 ${ }^{*}$, Mila Juliyanty Salampessy ${ }^{1}$, Faizah Salma Kaliky ${ }^{1}$
}

\author{
1 Program Studi Kuliah Kerja Lapangan Angkatan XLI, Jurusan Akuntansi Sekolah Tinggi Ilmu \\ Ekonomi Makassar Bongaya (STIEM BONGAYA) Jl. Let. Jend. Mappoddang No. 28, Bongaya, Kec. \\ Tamalate, Kota Makassar, Sulawesi Selatan 90131 \\ *Correspondent Email: fajrulrahman016@gmail.com
}

Article History:

Received: 15-12-2020; Received in Revised: 20-01-2021; Accepted: 09-03-2021

DOI: http://dx.doi.org/10.35914/tomaega.v4i2.553

\begin{abstract}
Abstrak
Salah satu yang sangat diharapkan oleh pemerintah negeri Hitumessing untuk masyarakatnya demi mencapai kesejahteraan dalam hidup adalah dapat mandiri, serta tidak serta merta menggantungkan apa yang diberikan pemerintah kepadanya melainkan untuk menciptakan lapangan kerja, seperti misalnya usaha dalam bidang jasa, kuliner, dan lainnya. Hal ini akan dibentuk melalui berbagai jenis usaha misalnya home industry, koperasi ataupun Usaha Kecil Menengah (UKM) Berhubung minimnya pengetahuan tentang penyusunan laporan keuangan oleh pihak (BUMneg) Ulihalawang maka kami selaku mahasiswa jurusan Akuntansi membantu mengatasi masalah penyusunan laporan keuangan pada (BUMneg) Ulihalawang, Tujuan dari edukasi ini untuk memahamkan pegawai dan staf (BUMneg) Ulihalawang tentang tata cara penyusunan laporan keuangan agar dapat memahami dan bisa membuat laporan keuangan dengan baik dan benar sesuai dengan SAK ETAP. Treatment yang diberikan setelah mendapatkan masalah riil di lapangan adalah dengan memberikan materi tentang penyusunan laporan keuangan secara tatap muka. pertama yaitu dengan membenahi aspek keuangan pada BUMneg Ulihalawang dan dilanjutkan dengan melakukan penyusunan laporan keuangan BUMneg Ulihalawang dengan benar. Selanjutnya kami menjelaskan kepada pihak BUMneg bagaimana melakukan penyusunan laporan keuangan ketika adanya transaksi masuk dan transaksi keluar, dan menjelaskan serta mempraktikkan tata cara atau proses penyusunan laporan keuangan yang dimana berawal dari pembuatan jurnal umum berdasarkan bukti-bukti transaksi yang ada, kemudian memposting ke buku besar berdasarkan akun-akun yang ada pada jurnal umum, selanjutnya memindahkan nilai-nilai yang ada pada buku besar ke neraca saldo berdasarkan akunnya, jika ada informasi tambahan di akhir bulan maka harus dibuatkan jurnal penyesuaian untuk mengetahui nilai suatu akun yang ada pada informasi tambahan tadi. Kemudian kami membantu pihak Bumneg dalam dalam membuat laporan keuangan per 30 juli sekaligus sebagai acuan kepada pihak BUMneg untuk membuat laporan keuangan dalam setiap kegiatan yang dilakukan oleh pihak BUMneg baik kegiatan rutin atau pun kegiatan tambahan.
\end{abstract}

Kata Kunci: Edukasi, Penyusunan Laporan Keuangan, BUMneg

\section{Abstract}

One of the things that the government of the black country highly hopes for its people in order to achieve prosperity in life is to be able to be independent, and not necessarily to depend on what the government gives to it but to create jobs, such as businesses in the service, culinary, and other fields. This will be formed through various types of businesses, for example home industry, cooperatives or small and medium enterprises (UKM) due to the lack of knowledge about the preparation of financial reports by the Ulihalawang village-owned enterprise 
(BUMNeg), so we as accounting students help overcome the problem of preparing financial reports at Ulihalawang village-owned enterprise, the purpose of this education is to understand the employees and staff of Ulihalawang village-owned enterprises about the procedures for preparing financial reports so that they can understand and be able to make financial reports properly and correctly in accordance with SAK ETAP. The treatment given after having real problems in the field is to provide material on the preparation of face-to-face financial reports. The first is to fix the financial aspects of the Ulihalawang village-owned enterprise and continue with the correct preparation of financial reports for the Ulihalawang village-owned enterprises. then we explain to village-owned enterprises how to prepare financial reports when there are incoming and outgoing transactions, and explain and practice the procedures or processes for preparing financial reports which begin with making general journals based on existing transaction evidence, then posting to the ledger based on the accounts in the general journal, then transfer the values in the ledger to the trial balance based on the account, if there is additional information at the end of the month, an adjusting journal must be made to determine the value of an account in the information extra earlier. then we assisted village-owned enterprises in making financial reports as of July 30 as well as a reference for village-owned enterprises to make financial reports in every activity carried out by village-owned enterprises either routine activities or additional activities

Keywords: Education, Preparation of financial statements, BUMneg

\section{Pendahuluan}

BUMneg Ulihalawang negeri Hitumessing telah ada sejak tahun 2019, dan dibentuk melalui inisiatif dari pemerintah negeri Hitumessing dengan tujuan untuk mewujudkan kesejahteraan masyarakat dan membantu masyarakat negeri Hitumessing dalam mencapai pembangunan nasional. Tujuan untuk mencapai pembangunan nasional, desa merupakan agen pemerintah terdepan yang dapat dijangkau kelompok sasaran riil yang hendak di sejahterakan, yaitu dengan membentuk suatu badan usaha yaitu badan usaha milik desa yang sesuai dengan permendagri Nomor 39 tahun 2010 tentang badan usaha milik desa (Ramadana, dkk., 2013). Menurut Peraturan Menteri Dalam Negeri Nomor 39 Tahun 2010, BUMDes merupakan usaha desa yang dibentuk/didirikan oleh pemerintah desa dimana kepemilikan modal dan pengelolannya dilaksanakan oleh pemerintah desa dan masyarakat. Menurut Permendesa PDTT nomor 4 tahun 2015 tentang pendirian, pengurusan, pengelolaan, dan pembubaran Badan Usaha Milik Desa dimaksudkan untuk melaksanakan ketentuan pasal 142 peraturan pemerintah nomor 43 tahun 2014 tentang peraturan pelaksanaan undang-undang nomor 6 tahun 2014 tentang desa, sehingga perlu menetapkan peraturan menteri desa, pembangunan daerah tertinggal, dan transmigrasi tentang pendirian, pengurusan, pengelolaan, dan pembubaran Badan Usaha Milik Desa (Permendesa PDTT Nomor 4 tahun 2015).

Salah satu bentuk kebijakan pembangunan desa untuk mencapai kesejahteraan masyarakat desa adalah dengan dibentuknya badan usaha milik desa (BUMDes) (Amanda, 2015). Badan Usaha Milik Desa (BUMDes) secara etimologi berasal dari beberapa kata yaitu badan usaha yang diartikan kesatuan yuridis (hukum), teknis, dan ekonomis yang bertujuan mencari laba atau keuntungan sedangkan milik dapat diartikan sebagai kepemilikan atau kepunyaan sementara desa adalah kesatuan wilayah yang 
dihuni oleh sejumlah keluarga yang mempunyai system pemerintah sendiri (KBBI). Dengan demikian, BUMDes merupakan usaha yang dilakukan oleh system pemerintah yang terdapat hukum yang menaungi secara teknis dalam sektor perekonomian masyarakat. Maryunani mendefinisikan bahwa BUMDes adalah lembaga usaha yang dikelola oleh masyarakat dan pemerintah desa dalam upaya memperkuat perekonomian desa dan membangun kerekatan sosial masyarkat yang dibentuk berdasarkan kebutuhan dan potensi desa (Maryunani, 2008).

Desa dapat mendirikan BUMDes dengan mempertimbangkan beberapa faktor yakni : 1) inisiatif pemerintah Desa dan /atau masyarakat desa; 2) potensi usaha ekonomi Desa; 3) sumberdaya alam di desa ; 4) sumberdaya manusia yang mampu mengelola BUMDes ; 5) penyertaan modal dan pemerintah desa dalam bentuk pembiayaan dan kekayaan desa yang diserahkan untuk dikelola sebagai bagian dari usaha BUMDes (permendesa no.4 tahun 2015).

Berdasarkan peraturan menteri desa, pembangunan daerah tertinggal dan transmigrasi nomor 4 tahun 2015 tentang pendirian, pengurusan dan pengelolaan, dan pembubaran badan usaha milik desa (BUMDes) pasal 12 ayat (3) bahwa pelaksanaan operasional berwenang : (1) membuat laporan keuangan seluruh unit-unit usaha BUMDes setiap bulan, (2) membuat laporan perkembangan kegiatan unit-unit usaha BUMDes setiap bulan (3) memberikan laporan perkembangan unit-unit usaha BUMDes kepada masyarakat desa melalui musyawarah desa sekurang-kurangnya 2 (dua) kali dalam 1 (satu) tahun. Berdasarkan permendes nomor 4 tahun 2015 tersebut. Salah satu cara untuk mendorong pembangunan di tingkat desa adalah pemerintah desa diberikan kewenangan oleh pemerintah pusat mengelola secara mandiri lingkup desa melalui lembaga ekonomi di tingkat desa (Budiono, 2015). Dan salah satu lembaga tersebut adalah Badan Usaha Milik Desa (BUMDes) (Agunggunanto dkk, 2016). Tujuan dari dibentuknya BUMDes merupakan upaya pemerintah untuk meningkatkan kemampuan keuangan pemerintah desa dalam penyelenggaraan pemerintah dan meningkatkan pendapatan masyarakat melalui berbagai kegiatan usaha ekonomi masyarakat pedesaan.

Pembangunan pada tingkat desa memiliki kelemahan antara lain disebabkan tidak hanya karena persoalan keuangan tetapi juga karena persoalan sumber daya manusia yang kurang berkualitas. Pemerintah telah melakukan berbagai upaya dengan mengeluarkan dana untuk program pembangunan desa yang mana salah satunya adalah (BUMDes) Badan Usaha Milik Desa (Prasetyo, 2016). Melihat posisi badan usaha milik desa dalam menghadapi realitas arus desa dalam pengembangan usaha sangat keras sekali, disamping itu badan usaha milik desa ini mempunyai modal yang tidak terlalu besar jika dibandingkan dengan swasta bermodal besar maka posisi badan usaha milik desa tidak dapat dibandingkan (Ramadana dkk, 2013) (Khairawati dkk, 2021).

Desa dipandang masih tertinggal jauh dibandingkan dengan kota baik dari segi ekonomi, kesejahteraan, pendidikan dan fasilitas lainnya. Pemerintah banyak melakukan program untuk mendorong percepatan pembangunan pedesaan, tetapi hasilnya belum signifikan dalam meningkatkan kesejahteraan masyarakat desa. Negeri 
Hitumessing merupakan salah satu desa di Kecamatan Leihitu Kabupaten Maluku Tengah yang mendirikan BUMDes dengan nama BUMNeg (badan usaha milik negeri) Ulihalawang Negeri Hitumessing, awal BUMNeg didirikan masih terdapat beberapa permasalahan seperti para pegawai BUMNeg sebagian besar belum memahami laporan keuangan. Setelah melakukan observasi terhadap BUMNeg Ulihalawang, maka permasalahan yang dihadapi BUMNeg Ulihalawang adalah kurangnya pemahaman tentang penyusunan laporan keuangan. Setelah mendapatkan informasi yang dibutuhkan, selanjutnya kami memberikan solusi kepada pihak BUMNeg yaitu dengan memberikan pemahaman mengenai edukasi penyusunan laporan keuangan dengan cara melakukan sosialisasi tentang pentingnya pencatatan akuntansi dan penyusunan laporan keuangan BUMDes.

Laporan keuangan yang bertujuan untuk menyajikan informasi mengenai posisi keuangan, realisasi anggaran, arus kas dan kinerja keuangan suatu entitas pelaporan yang bermanfaat bagi para pengguna dalam membuat dan mengevaluasi keputusan mengenai alokasi sumber daya (Fisu dkk, 2020). Nurlan (2008) menjelaskan tujuan pelaporan keuangan pemerintah adalah menyajikan informasi yang berguna untuk pengambilan keputusan untuk menunjukan akuntabilitas entitas pelaporan sumberdaya yang dipercaya kepadanya. Secara umum sistem pelaporan keuangan BUMDes memiliki kesamaan dengan lembaga lain terutama lembaga usaha. Dalam hal ini setiap kali ada transaksi masuk dan transaksi keluar harus dicatat oleh pihak BUMDes dengan menggunakan kaidah akuntansi yang mudah dipahami, karena laporan keuangan ini akan diperiksa kembali oleh pihak tertentu.

Laporan keuangan sangat penting bagi BUMDes karena laporan keuangan akan memberikan informasi dalam perkembangan BUMDes seperti laporan rugi/laba dan modal yang dikeluarkan. Melalui kegiatan ini diharapkan pegawai BUMneg dapat memahami cara penyusunan laporan keuangan. Yang pada akhirnya pegawai BUMneg dapat membuat laporan keuangan dengan baik dan benar untuk mempermudah pertanggung jawaban pada saat rapat kerja.

\section{Metode}

Terdapat beberapa metode yang kami gunakan yang pertama yaitu pendidikan masyarakat, digunakan untuk kegiatan-kegiatan, seperti a) pelatihan semacam in-house training, b) penyuluhan yang bertujuan meningkatkan pemahaman serta kesadaran, dan sebagainya. Yang kedua metode yang kami gunakan yaitu metode statistik deskriptif. Statistik deskriptif atau statistik deduktif adalah bagian dari statistik yang mempelajari cara pengumpulan dan penyajian data sehingga mudah dipahami. Statistik deskriptif hanya berhubungan dengan hal menguraikan atau memberikan keterangan-keterangan mengenai suatu data atau keadaan atau fenomena. Dengan kata lain, statistik deskriptif hanya menerangkan keadaan, gejala, atau persoalan (Hasan, 2013). 
Statistik deskriptif berfungsi untuk mendiskripsikan atau memberi gambaran terhadap objek yang diteliti melalui data sampel atau populasi (Sugiyono, 2007). Usaha kecil dan menengah menurut Gozali (2017) penelitian deskriptif kualitatif yaitu jenis penelitian yang berusaha menggambarkan dan menginterpretasi objek sesuai dengan keadaan sebenarnya. Kami memilih analisis menggunakan metode ini karena kami ingin memberikan gambaran. (UKM) merupakan suatu bentuk kegiatan berwirausaha ditengah-tengah masyarakat dengan inisiatif individual seseorang guna mendorong pertumbuhan ekonomi masyarakat sekitar.

Kami melakukan observasi secara disiplin pada BUMNeg Ulihalawang, agar bisa mendapatkan informasi terkait masalah apa yang terdapat dalam BUMNeg Ulihalawang. Setelah mengadakan Observasi maka dapat diketahui permasalahan yang dihadapi yaitu kurangnya pengetahuan tentang penyusunan laporan keuangan oleh pegawai BUMNeg. Selanjutnya kami dengan pihak BUMneg mencari jalan keluar untuk membenahi masalah tentang penyusunan laporan keuangan tersebut.

Pertama yaitu dengan mengadakan sosialisasi tentang pentingnya pemahaman penyusunan laporan keuangan bagi pihak BUMNeg Ulihalawang yang sesuai dengan kaidah penyusunan laporan keuangan. Kegiatan ini dilakukan secara tatap muka kepada seluruh staf BUMneg Ulihalawang, materi yang diberikan terkait dengan penyusunan laporan keuangan. Variabel yang terlibat dalam penelitian ini adalah Laporan keuangan. Laporan keuangan merupakan laporan yang berisi informasi yang dibutuhkan untuk melihat kondisi keuangan perusahaan. Laporan keuangan menurut Ikatan Akuntan Indonesia (2015) dalam standar akuntansi keuangan (SAK) No. 1 dikemukakan bahwa laporan keuangan merupakan bagian dari proses keuangan dan kinerja keuangan suatu entitas. Menurut Kasmir (2018) Laporan keuangan adalah laporan yang menunjukkan kondisi keuangan perusahaan pada saat ini atau dalam suatu periode tertentu. Menurut Said (2008) Laporan keuangan merupakan rangkuman akhir dari suatu aktivitas usaha baik berbentuk usaha perseorangan, perdagangan, industry maupun bentuk-bentuk usaha lainnya. Dalam pemahaman sumber pengelolaan dana BUMneg masih bergantung pada dana pemerintah, Sehingga perusahaan dapat mengetahui tingkat keuntungan dan kerugian dari hasil usaha mereka.

\section{Hasil dan Pembahasan}

Berdasarkan penyusunan Laporan keuangan pada tahun 2019 pihak BUMneg Ulihalawang mendapatkan modal sebesar Rp 50.000.000, dari Kepala Desa (Bapak Raja) untuk membuka suatu usaha di Desa Hitumessing yaitu usaha BRI link yang dikelola oleh pegawai BUMneg itu sendiri. Laporan keuangan yang disusun oleh pihak BUMneg Ulihalawang masih berupa catatan, buku tulis, dan laporan laba rugi berdasarkan pengeluaran dan pemasukan, sehingga laporan keuangannya belum sesuai dengan SAK ETAP.

Adapun Edukasi dilakukan agar pegawai dan staf BUMneg Ulihalawang dapat mengetahui dan memahami tata cara penyusunan Laporan Keuangan baik dalam segi 
pencatatan maupun pelaporan (Stiem Bongaya, 2020). Edukasi berfokus pada pegawai dan staf BUMneg Ulihalawang Negeri Hitumessing Kecamatan Leihitu Kabupaten Maluku Tengah. Dimana Pegawai dan staf BUMneg diberikan penjelasan mengenai tata cara penyusunan Laporan Keuangan. Berikut merupakan edukasi yang dilakukan yaitu Edukasi presentasi tata cara penyususan laporan keuangan.

Tujuan dari edukasi ini untuk memahamkan pegawai dan staf (BUMneg) Ulihalawang tentang tata cara penyusunan laporan keuangan agar dapat memahami dan bisa membuat laporan keuangan dengan baik dan benar sesuai dengan SAK ETAP.

Kegiatan ini dilakukan pada kamis, 27 agustus 2020 yaitu tentang penyusunan laporan keuangan dan dihadiri oleh sebagian staf BUMneg Ulihalawang dan pengawai Kantor Desa karena sebagian pegawai dan staf berhalangan hadir, pemateri berinteraksi langsung dengan pengelola BUMneg Ulihalawang dalam penyampain tata cara penyusunan laporan keuangan dan memberikan saran-saran dalam mengelola dana BUMneg Ulihalawang kedepannya agar lebih transfaran dan akuntabel sehingga kesejahtaraan masyarakyat dapat terjamin, selain itu pemateri juga menjelaskan bagaiamana melakukan penyusunan laporan keuangan ketika adanya transaksi masuk dan transaksi keluar agar tidak salah pada saat akan membuat laporan keuangan nantinya.

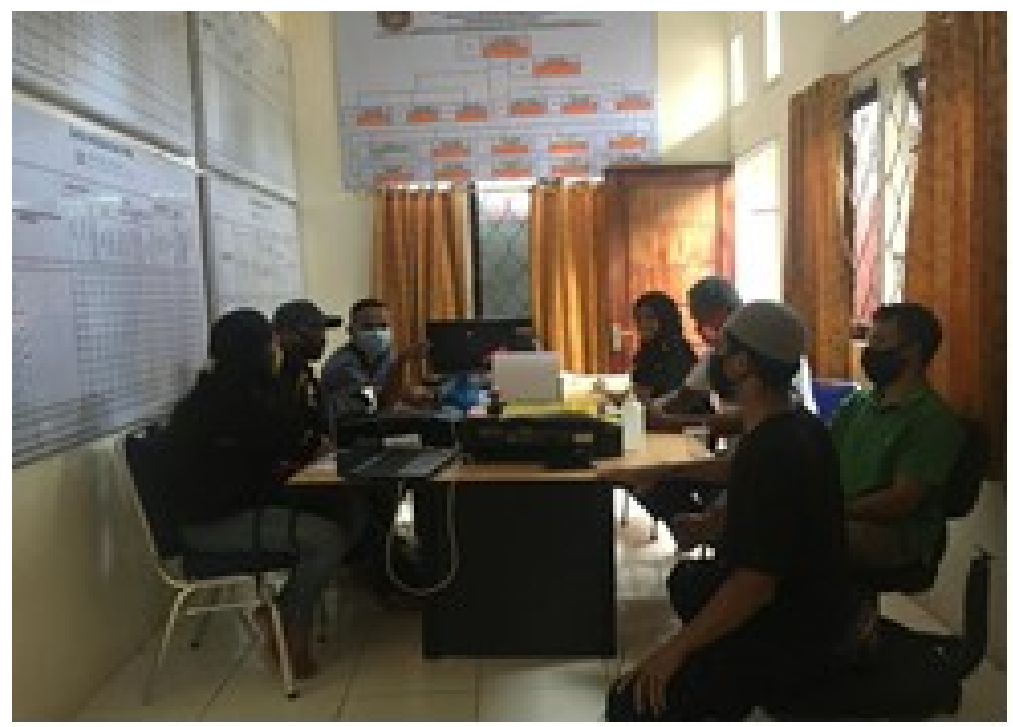

Gambar 1. Suasana Penyampain Tentang Penyusunan Laporan Keuangan Kepada Para Pegawai dan staf BUMneg Ulihalawang

Dengan adanya sosialisasi ini terungkap bahwa BUMneg Ulihalawang memiliki masalah dalam pencatatan akuntansi dan penyusunan laporan keuangan, dikarenakan staff BUMNeg tidak ada lulusan akuntansi ataupun yang berkaitan dengan akuntansi. BUMNeg Ulihalawang ini sudah memiliki laporan keuangan tetapi masih belum sesuai dengan SAP ETAP. Penyusunan laporan keuangan BUMneg Ulihalawang masih menggunakan cara manual yang dicatat pada buku jurnal. 


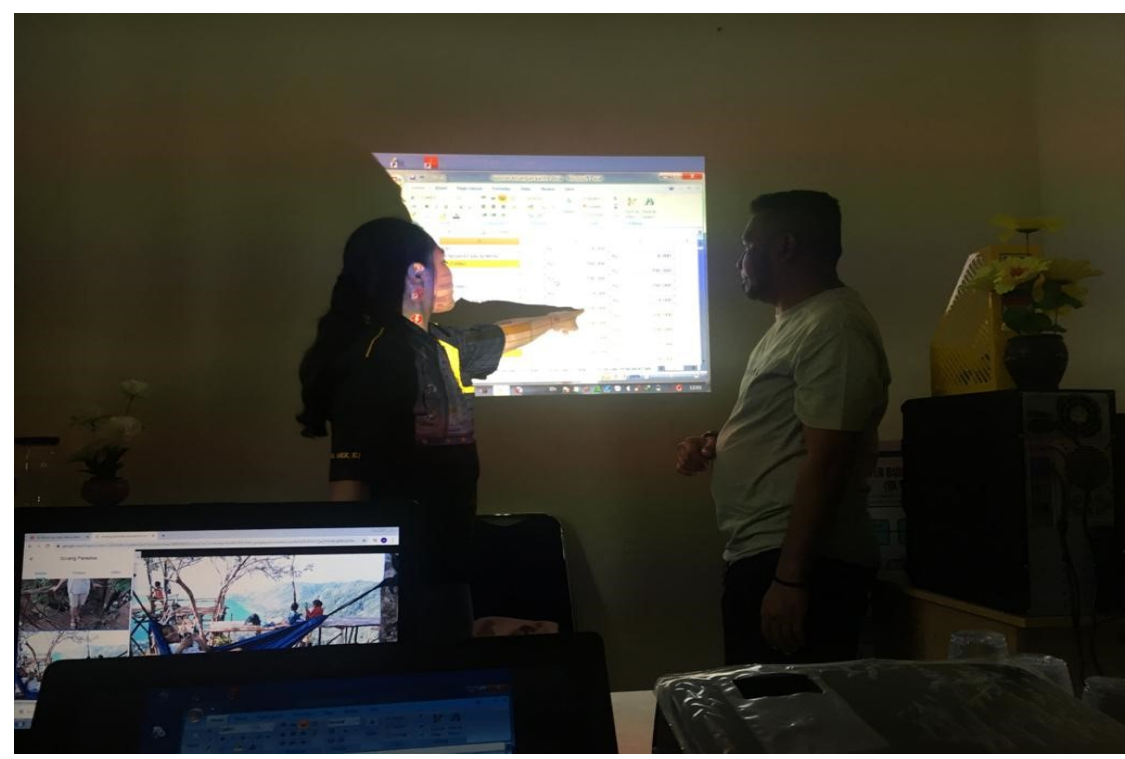

Gambar 2. Proses Bimbingan Tentang Pencatatan Akuntansi Dan Penyusunan Laporan Keuangan

Pada gambar 2 tersebut, Pemateri memberikan sedikit pemahaman kepada pengelola BUMneg dalam penyusunan laporan keuangan BUMneg terkhususnya untuk penyusunan laporan keuangan BRIlink bahwa dalam penyusunan keuangan BRIlink lebih mudah menggunakan excel dibandingkan dengan cara manual. Disamping itu pemateri juga memberikan sedikit wawasan kepada pengelola BUMneg mengenai penyusunan laporan keuangan yang sesuai dengan SAP ETAP. pemateri juga memberikan tata cara atau proses penyusunan laporan keuangan yang dimana berawal dari pembuatan jurnal umum berdasarkan bukti-bukti transaksi yang ada, kemudian memposting ke buku besar berdasarkan akun-akun yang ada pada jurnal umum, selanjutnya memindahkan nilai-nilai yang ada pada buku besar ke neraca saldo berdasarkan akunnya, jika ada informasi tambahan di akhir bulan maka harus dibuatkan jurnal penyesuaian untuk mengetahui nilai suatu akun yang ada pada informasi tambahan tadi.

Selanjutnya kami membantu pihak BUMneg dalam membuat laporan keuangan per 30 juli sekaligus sebagai acuan kepada pihak BUMneg untuk membuat laporan keuangan dalam setiap kegiatan yang dilakukan oleh pihak BUMneg baik kegiatan rutin atau pun kegiatan tambahan. Dalam bentuk laporan harian, mingguan, bulanan dan tahunan.

\section{Kesimpulan}

BUMneg Ulihalawang negeri Hitumessing telah ada sejak tahun 2019, dan dibentuk melalui inisiatif dari pemerintah negeri Hitumessing. Salah satu usaha yang dibentuk oleh BUMNeg adalah BRIlink untuk mempermudah warga Hitumessing dalam melakukan transaksi antar bank. Pembuatan BRIlink ini mendapat modal dari 
kepala desa Hitumessing. Pengelolaan BRIlink telah berjalan dengan baik tetapi pencatatan akuntansi dan penyusunan laporan keuangan belum sesuai dengan kaidah SAP ETAP. Kegiatan ini berjalan dengan lancar dan mendapat dukungan dari staff BUMNeg dan pemerintah desa Hitumessing.

\section{Ucapan Terimakasih}

Kami mengucapkan terima kasih yang sebesar-besarnya kepada STIEM Bongaya, terlebih kepada pihak LP3M, Pembimbing dan Pemerintah Negeri Hitumessing atas bantuan dan bimbingan kepada kami baik berupa bimbingan, waktu, dan tenaga. Adanya kerja sama yang baik dari pihak BUMNeg sehingga mempermudah kami dalam melakukan Pengabdian Masyarakat ini.

\section{Daftar Pustaka}

Agunggunanto, E. Y., Arianti, F., Kushartono, E. W., \& Darwanto (2016).Pengembangan Desa Mandiri melalui Pengelolaan Badan Usaha Milik Desa (BUMDes). Jurnal Dinamika Ekonomi dan Bisnis, 13(1), 67-81.

Amanda, H. (2015). Strategi Pembangunan Desa Dalam Meningkatkan Pendapatan Asli Desa Melalui Badan Usaha Milik Desa. Publika, vol 3, no 5.

Budiono, P. (2015). Implementasi Kebijakan Badan Usaha Milik Desa (BUMDes) di Bojonegoro (studi di desa Nginginrejo Kecamatan Kalitidu dan Desa Kedungprimpen Kecamatan Kanor). Jurnal politik muda, 4(1), 116-125.

Berdesa. 2017. Kenapa Laporan Keuangan BUMDes Begitu Penting. Diunduh dari https://www.berdesa.com/kenapa-laporan-keuangan-bumdes-begitu-penting/ (diakses tanggal 30 januari 2021)

Fisu, A. A., Didiharyono, D., \& Bakhtiar, B. (2020). Economic \& Financial Feasibility Analysis of Tarakan Fishery Industrial Estate Masterplan. In IOP Conference Series: Earth and Environmental Science (Vol. 469, No. 1, p. 012002). IOP Publishing.

Hasan, Iqbal. (2013). Pokok-Pokok Materi Statistik 1 (Statistik Deskriptif). Bandung Afabeta.

Khairawati, S., Widodo, S., \& Hadi, S. N. (2021). Pelatihan Bagi Karyawan KSPPS Al Huda Wonosobo Untuk Menilai Kelayakan Usaha Calon Anggota. To Maega: Jurnal Pengabdian Masyarakat, 4(1), 81-89.

Maryunani.Pembangunan BUMDes dan Pemberdayaan Pemerintah Desa, (Bandung: CV. Pustaka Setia, 2008). hlm.35

Darise, Nurlan. 2008. Akuntansi Keuangan Daerah. Cetakan Pertama. PT. Indeks. Jakarta. 
Ramadana, C. B., Ribawanto, H., \& Suwondo.(2013). Keberadaan Badan Usaha Milik Desa (BUMDES) sebagai penguatan ekonomi desa.Jurnal administrasi publik 1 (6), $1068-1076$.

Ratna, A. P., (2016). Peranan BUMDES dalam Pembangunan dan Pemberdayaan Masyarakat di Desa Pejambon Kecamatan Sumberrejo Kabupaten Bojonegoro.Jurnal Dialektika 11 (1), 86-100.

Republik Indonesia, Peraturan Menteri Dalam Negeri Tentang Badan Usaha Milik Desa, Permendagri No. 39 Tahun 2010

Republik Indonesia, Peraturan Menteri Desa PDTT Tentang Badan Usaha Milik Desa, Permendesa PDTT Nomor 4 tahun 2015

Republik Indonesia, Peraturan Pemerintah Tentang Desa, PP Nomor 6 Tahun 2014 